\title{
Introduction: Jews, Shechita, and the Law
}

\section{The Historical and Linguistic Stakes}

I $\mathrm{n}$ the spring of 1913, Abraham Levitt, rabbi of the small Jewish community in Halifax, Nova Scotia was charged on the information of an inspector of the Society for the Prevention of Cruelty, with inflicting ill-treatment on, and causing unnecessary suffering to, a heifer. According to the local newspaper coverage of the case, this was "the first time in American history that a rabbi has been haled before the courts in a case of this kind."1

After a hearing lasting several days, Levitt was convicted and fined six dollars plus seven dollars and sixty-five cents in costs. For the first time in the history of the American continent a Jewish rabbi had been fined for killing an animal according to the Jewish belief, namely by cutting its throat without prior stunning. ${ }^{2}$ The historian of Montreal and Canadian Jewry, David Rome, later wrote that, "because Halifax is so distant from the centres of Canadian Jewry a very important anti-Semitic case in that city, classic in its form, received very little attention and has since been virtually lost to memory." 3

This book remedies the gap identified by Rome by returning the Halifax case to our collective legal and historical memory. It interrogates the often-competing discourses of the anti-cruelty movement in the early twentieth century, narrow positivistic renderings of legal texts, and ideas of religious

1 “The Halifax Hebrew Rabbi Is Before Stipendiary Magistrate's Court," Halifax Herald, April 2, 1903.

2 “Jewish Rabbi Fined by the Stipendiary," Halifax Herald, April 22, 1913.

3 The Jewish Biography of Henri Bourassa, 94. 
freedom and practice that circulated around, and informed the context of, the prosecution of Rabbi Levitt. It is necessary to place events in Halifax in 1913 in broader social, political, and socio-legal historical contexts that surrounded local, national, and international debates about animal welfare and about the place of growing Jewish communities in North America. At first blush, the singular prosecution of Abraham Levitt, apparently the only recorded instance of an animal cruelty case and conviction of a Jew engaged in the religiously ordained killing of an animal in North American legal history, might seem to be a minor historical event at the geographical and demographic margins of Canada, North America, and the British Empire. This study highlights the ways in which this singular instance of legal prosecution embodied matters of historical, social, and cultural significance that went far beyond the fate of Abraham Levitt and the small Jewish community of Halifax. It brings to light other instances of attempts to criminalize Jewish religious slaughter in the common-law world, demonstrating how and why the singular instance of the Halifax case was, contrary to coverage at the time, not at all singular. Instead it fits into a pattern of actions by animal welfare groups targeting the Jewish method of slaughtering animals for food over a significant period of time and in a variety of jurisdictions. I seek to recover for historical memory the vital role of these anti-shechita prosecutions in the legal and social history of Jewry in the different places they occurred.

By bringing to light these other attempts to criminalize and abolish shechita, the process of interrogating the hermeneutic and narrative similarities that informed each of these now somewhat obscured legal instances, in which observant Jews were prosecuted for practices central to their religious identity in the name of humane values, can begin. The prosecution of Abraham Levitt in Halifax on the eve of the First World War was not as singular or isolated as David Rome believed. An important goal of this study is to begin to trace a socio-legal history of attempts in the English-speaking world to criminalize the practice of the Jewish mode of killing animals in the name of the competing value of animal welfare and to interrogate the hows and whys of legal processes that contrast in a negative and harmful way, humane values and Jewish religious observance. Each instance highlights the common conflicts that occurred in the legal regulatory realm as a public good, animal welfare, encountered another public good, the need to recognize and accommodate religious practice. While each clearly occurred at different times and in distinct geographical spaces, neither Jewish communities nor animal welfare groups acted in complete isolation from their fellows, nor did they always operate in ignorance of the 
real legal history of attempts to criminalize the Jewish method of slaughter. Networks of knowledge, shared values and history, and group solidarity operated on both sides of these struggles.

The Halifax case of 1913 underscores the ways in which discourses of solidarity among Canadian Jewish communities were at play, as were national and transnational practices and networks of knowledge relating to the anticruelty movement in Canada, the United States, and the United Kingdom. The Halifax legal action must be understood not just in relation to the specificities of the case itself, but in these contexts and discourses that went well beyond a single conviction of a solitary Jew in a small Jewish community at the geographic and social fringes of the Canadian federation, the British Empire, and Canadian Jewry. The patterns that emerge in these cases will elucidate the fashion in which Jewish communities have been forced to struggle for recognition and equality in the midst of social, cultural, political (and legal) contexts that invoked a fundamental distinction between the normal and Christian human spirit and a Jewish world tainted by an equally Christian imaginary around the central trope of blood. ${ }^{4}$

Societies for the Prevention of Cruelty to Animals or Humane Societies did not hesitate to claim that their sole aim was the protection of "God's dumb animals" and that they acted from this moral and theological imperative. Jewish communities defended shechita in terms of their obligations as observant practitioners of their faith. The anti-shechita prosecutions bring to the light the difficult, if not impossible, task involved in the historical articulation of a broadly acceptable and accepted social, political, moral, and juridical position in cases where each claimant invokes holy writ in demanding the legal recognition and embodiment of its claims. When Abraham Levitt killed the heifer in a slaughterhouse in Halifax in the spring of 1913, he did so as part of his duties as shochet, an individual trained in the killing of animals according to the methods prescribed by Jewish law. For observant Jews, the shochet "is more like a High Priest, for he must be a god-like man, a skillful [sic] man in his profession; a learned man, who chooses this humble and dangerous calling, because he believes it his mission to so serve not only his generation; but the generations to come."

4 Anthony Bale and David Feldman, eds., Blood: Reflections on What Unites and Divides Us (Oxford: Shire, 2016).

5 Friedman Family / Friedman, Aaron / Aaron's Life as Shochet / n.d. Friedman Family Papers; P-948; Box 1, Folder 1, American Jewish Historical Society, New York and Boston. 
The cow had been dispatched according to the Jewish method of killing, shechita. While it is still common to deploy the terms "ritual killing" or "ritual slaughter" to describe shechita, I adopt the less morally fraught, and historically problematic, "Jewish method" or "Jewish mode" formulations. The slippage, and the linkage made, between accusations of Jewish ritual murder of Christian children in the blood libel, and a signifying chain of Jewish brutality and blood lust associated with shechita, has been present in anti-Judaic discourse and legal practice throughout the nineteenth and twentieth centuries. ${ }^{6}$ Fantasies about Jews engaging in ritual murder were linked to the meanings associated with the reality of ritual slaughter at the turn of the century. Interlocking discourses of murder and ritual slaughter are present in the world of literary representation as well as in the rhetoric of the blood libel accusations of the time. ${ }^{7}$

Anthony Julius, in his monumental study of English antisemitism, examines the semantic and rhetorical elisions and connections between the use of terms such as ritual slaughter and the ritual murder accusation as antisemites joined animal welfare and anti-cruelty debates. ${ }^{8}$ The two competing principles at play in the controversies over shechita, a practice performed as a result of religious obligation, and an opposing deontological assertion about the welfare of animals, call for carefully elaborated ethical normative engagements between the parties. However, the signifier "ritual slaughter" carries with it a clear message, especially when paired or contrasted with ideals of the humane, as Brian Klug has argued, of a contrast between a civilized and humane Us and a savage and merciless Other, the Jew. ${ }^{9}$ Throughout modern British and other debates about the relationship between shechita and claims of animal suffering during slaughter, phrases such as "Jewish mode of slaughter," "the Jewish method," "the Jewish mode," or "Jewish rules" have been used interchangeably in order to avoid the potential slippage into pernicious and dangerous antisemitic tropes. Because antisemitism is one of the organizing discourses that informed debates in the cases of attempted criminalization of Jewish practices, I adopt Julius' preferred formulations when discussing shechita.

\footnotetext{
6 Richard Weisberg, ed., A Thousand Years of Infamy: The History of the Blood Libel, 28 Law and Literature (2016).

7 Sander L. Gilman, “Kafka Wept,” Modernism/Modernity 1, no. 1 (1994):18.

8 Trials of the Diaspora: A History of Anti-Semitism in England (Oxford: Oxford University Press, 2010), 341-342.

9 “The animal welfare lobby is wrong," Guardian, June 11, 2003.
} 


\section{Shechita, Religious Obligation, and Animal Welfare}

The approved mode of killing animals so that they might be consumed fits more broadly into the complex and multifaceted set of Jewish dietary laws known as kashrut. For the observant Jew, the dietary laws form an essential part of religious experience and being, although it is worth noting that kashrut does not compel individual Jews to consume meat. It simply provides that meat that is to be consumed must come from animals slaughtered according to the rules of shechita. The laws of kashrut are understood and practiced as religious and ethical obligations that go to the heart of Jewish existence. "To acknowledge God in all one's ways is a short expression of the fundamental conception of Judaism that divine worship is not confined to prayer or to religious service in the House of God but is inherent in every facet of life, even in the matter of sustenance." 10

In shechita, the animal is slaughtered according to the prescriptions of the Torah and the Talmud. ${ }^{11}$ In Jewish law, the animal must be sound, with no indication of illness or injury. Because the use of a bolt, electric shock, or other method, to stun the animal into unconsciousness, before killing, would by necessity cause physiological change, and injury, the Jewish method requires that the animal be killed without being stunned. ${ }^{12}$ One swift cut with an extremely sharp knife, created specifically for this purpose, and itself subject to strict regulations (a hallaf or sakin), in the hands of a trained shochet "causes no pain, and takes a fraction of second." 13

The case against the shochet in Halifax was formed within the semiotics the aim of which was protecting animals from unnecessary suffering. The prosecution charged that Rabbi Levitt, in pursuing the Jewish method, had caused cruelty to be inflicted on the animal. The evidence led by the authorities

10 I. Grunfeld, The Religious and Moral Basis of the Jewish Dietary Laws (London: National Council of Shechita Boards, 1966), 1.

11 The divine injunction informing the Jewish method of slaughter comes among other sources from the text of Deuteronomy XII, 21 and from the Babylonian Talmud, Tractate Hullin, and codifications by Maimonides and Karo and other sources. Bernard Homa, Shehita (London: Soncino Press/Board of Deputies of British Jews, 1967).

12 S.I. Levin and Edward A. Boyden, The Kosher Code of the Orthodox Jew (Minneapolis: University of Minnesota Press, 1940); C.G. Montefiore, "Dr. Wiener on the Dietary Laws," Jewish Quarterly Review 8, no. 3 (1896); and M. Hyamson, "Another Word on Jewish Dietary Laws," Jewish Quarterly Review 9, no. 2 (1897).

13 Michael L. and Eli Munk, eds., Shechita: Part II of "Edut Ne'emana: Religious and Historical Research on the Jewish Method of Slaughter (Brooklyn: Gur Aryeh, 1976), 11. 
against Levitt alleged that the heifer issued loud noises as it thrashed about, evidencing almost in and of itself, the suffering and unnecessary pain inflicted by the shochet. The rabbi's defense, at the first stage at least, engaged with the animal cruelty allegation in terms that have informed the Jewish defense of shechita throughout the nineteenth, twentieth, and twenty-first centuries. For Levitt and his attorneys, as well as the medical experts who testified in his behalf, the Jewish method, with its swift single cut, was much less cruel than the common slaughterhouse method of animal stunning. This defense of the Jewish method of killing confronted allegations of animal cruelty directly and on their own terms, invoking modern medical and physiological science. Defenders of the Jewish method attacked the not always subtle assertions by opponents of shechita that the practice was a per se violation of a moral code demanding human kindness to animals. In a core text written to rebut animal protectionist allegations about the inherent and immoral cruelty of shechita, leading rabbi and shochet Aaron Z. Friedman offered both a physiological justification for the Jewish method and a theological/ethical explanation for the preferability of shechita. "And from the very beginning, when God created His creatures and ordained that animals should serve for human food, He commanded the Israelites to alleviate the pains and sufferings of animals by killing them in this kind way of Shechitah [sic]."14

Debates about the Jewish mode of slaughter embodied in the Halifax case gave voice to the multiple discourses that informed discussions and polemics about shechita throughout the nineteenth and twentieth centuries and that continue to this day. There were (and are) arguments about cruelty and ethical duties to animals, as well as unsubtle claims of the superiority of Christian morality over crude and primitive Jewish practice. The Halifax case, perhaps long forgotten or marginalized, offers useful insights into debates about animal cruelty and early manifestations of discourse about the meaning and content of ideals of religious freedom at the edges of Canada, North America, and the British Empire.

\section{The Halifax Jewish Community}

Writing in the early 1980s, Terrence Murphy described the state of Jewish history in Atlantic Canada as "still in its infancy." 15 While the stories of the Jewish

14 Laemlein Buttenwieser, trans., Tub Taam or a Vindication of the Jewish Mode of Slaughtering Animals for Food Called Shechitah ( $2^{\text {nd }}$ ed) (New York: Bloch Publishing, 1904), 25.

15 "The Religious History of Atlantic Canada: The State of the Art," Acadiensis 15, no. 1 (1985): 173. 
populations of the Atlantic provinces, and of Halifax, have been presented in subsequent studies, this history has been recounted largely as part of the broader Canadian or North American Jewish narrative, ${ }^{16}$ or as an introduction to sociological or political accounts of the state of contemporary Jewish communities, particularly those situated outside the major population centers. ${ }^{17}$ While this is not the place to offer a more complete history of the Halifax Jewish community, it is necessary to set out some context for the events surrounding Rabbi Levitt's conviction for animal cruelty in the spring and summer of 1913.

The historical accounts of Halifax Jewry that do exist offer a common narrative. A significant presence of Jewish merchants in Halifax can be found from the city's founding in 1749 as a key port and garrison during the British war with the French. ${ }^{18}$ The period of the War of Independence saw a further influx of Jewish individuals from Rhode Island and other American colonies. ${ }^{19}$ There was a strong enough presence of Jews in Halifax for the purchase and setting aside of land in the city's cemetery for a Jewish burial area, although there is no evidence that it was ever used for this purpose. Nor is there any documentation to support the existence of a Jewish burial society, a Chevra Kaddisha, a key historical indicator of an active Jewish community. ${ }^{20}$ Over the next century the identifiable Jewish presence in Halifax dissipated and what was left was a diminishing number of individuals with "Jewish" surnames scattered throughout Nova Scotia, but little or no indication of a separate, identifiably Jewish community.

The influx of European Jews to North America in the 1880s and 1890s saw a renewed presence in Halifax. As the major port in Atlantic Canada, the city was a point of disembarkation for thousands of immigrants to North

16 Gerald Tulchinsky, Taking Root: The Origins of the Canadian Jewish Community (Hanover, NH: University Press of New England, 1993), 82 et seq.; Sheldon J. Godfrey and Judith C. Godfrey, Search Out the Land: The Jews and the Growth of Equality in British Colonial America, 1740-1867 (Montreal: McGill-Queen's University Press, 1995), 73-81.

17 A. Ronald Gillis and Paul C. Whitehead, "The Halifax Jews: A Community within a Community," in Immigrant Groups, ed. Jean Leonard Elliott (Scarborough ON: Prentice Hall, 1971), 84-94; Sheva Medjuck, Jews of Atlantic Canada (St. John's, NL: Breakwater, 1986); Shari L. Brotman and James L. Torczyner, The Changing Portrait of Jewish Life in Halifax (Halifax, NS: McGill Consortium for Ethnicity and Strategic Social Planning, 1997).

18 Jacob Rader Marcus, Early American Jewry: The Jews of New York, New England and Canada, 1649-1794 (Philadelphia: Jewish Publication Society of America, 1961), 200.

19 Tulchinsky, Taking Root, 83.

20 Godfrey and Godfrey, Search Out the Land, 77, 79; David Wachtel, "Jewish Burial Societies: The Origins and Development of the Hevra Kaddisha," Jurist 59 (1999). 
America and has been described as "Canada's Ellis Island." ${ }^{21}$ While many of these immigrants moved on to other parts of the country or south to the United States, some stayed and the Jewish community of Halifax was reborn. The 1881 Canadian census reveals a total of fifteen identified Jews, born in Germany, the United States, and Canada. ${ }^{22}$ By 1891 , while the numbers had barely changed, the place of birth of the individuals or their parents clearly indicates an increasing presence of Russian and Polish Jews in Halifax. ${ }^{23}$ The growth in numbers at the time of the next census in 1901 is significant throughout the province and specifically in Halifax. In 1881 there were thirty-two Jews in the entire province of Nova Scotia and by 1901, the number had risen to $449 .{ }^{24}$ The newly arrived Jews came from central and eastern Europe and occupied roles across the middle and lower middle class sections of the economy, working as tailors, traders, merchants, clothiers, jewelers, peddlers, dressmakers, junk dealers, and included an optician. ${ }^{25}$ By 1911 , two years before the shechita prosecution, the number of Nova Scotia Jews had reached 1,360. ${ }^{26}$ While the population of the province grew by seven point thirty-five per cent in the decade 1901 to 1911 , the still small Jewish population increased by over 200 per cent. ${ }^{27}$ Tulchinsky points out that "these statistics reveal that the Jewish population of Canada was spreading out to smaller urban places in response to expanding economic opportunity." 28

The Halifax Jewish community, now united as a congregation, but still without a synagogue, adopted its name in honor of the European philanthropist Baron de Hirsch. It played an active role in rendering assistance to newly arrived immigrants from Europe, those who wished to settle, and those who arrived with the intention of moving on. ${ }^{29}$ In 1890 , the secretary of the Jewish community in Halifax entered into contact with the first non-synagogal Jewish

21 Stuart Rosenberg, The Canadian Jewish Community, Vol.1 (Toronto: McClelland and Stewart, 1970), 108.

22 Glen Eker and Deborah Pekilis, Index of Jews Resident in New Brunswick, Nova Scotia and Prince Edward Island According to the 1861 to 1901 Censuses of Canada (Toronto: Ontario Genealogical Society, 2004), 9.

23 Ibid., 16-17.

24 Louis Rosenberg, Canada's Jews: A Social and Economic Study of Jews in Canada in the 1930s, ed. Morton Weinfeld (Montreal: McGill-Queen’s University Press, 1993), 20.

25 Eker and Pekilis, Index of Jews, 36-39.

26 Rosenberg, Canada's Jews, 20.

27 Ibid., 12.

28 Taking Root, 159.

29 Baron De Hirsch Congregation 1890 to 1990: 100 th Anniversary Commemorative Book (Halifax, NS: Beth Israel Synagogue, 1990). 
xvi $\mid$ Introduction: Jews, Shechita, and the Law

organization in Canada, the Young Men's Hebrew Benevolent Society in Montreal, to seek assistance in extending relief to disembarking immigrants. ${ }^{30}$ Jewish Haligonians still worshipped in a number of temporary facilities. In these early days of communal life, religious ceremonies were held in individual homes. As the number of Jews grew, services were moved to premises made available by fraternal organizations such as the Masons and Oddfellows. In the mid-1890s, the seventeen Jewish families in Halifax, with the assistance of "Christian friends" purchased and refurbished the former Free Baptist Church on Starr Street that was dedicated as the Baron de Hirsch synagogue in February 1895. ${ }^{31}$ Throughout this time, relations with the dominant Christian communities of Halifax, particularly the various Protestant denominations, appear to have been warm. Leading Protestants assisted the community by providing facilities for worship and subscribed to the fundraising drive for the new synagogue. The local immigration agent in Halifax, Edward Cleary, himself a Free Baptist minister, was described as "very considerate" to newly arrived Jewish immigrants. The rejection rate for Jews seeking permission to land in Halifax was the lowest in Canada. ${ }^{32}$

This is not to suggest that the history of Jewish life in Halifax was or is devoid of antisemitism. The history of the province of Nova Scotia is underscored by the divisions between Roman Catholicism and various Protestant denominations, including the Anglican and Presbyterian elites. If intraChristian religious disputes and an ultimate modus vivendi grounded in institutional structures recognizing the splits are at the heart of the history of Nova Scotia and Halifax, one could hardly expect an absence of Christian antisemitism. The prosecution of Rabbi Levitt cannot be understood without taking into account the grossly anti-Jewish motifs at play in the case and abroad in the country more generally. ${ }^{33}$ At the same time, the history of the Halifax Jewish community in the 1890 s and into the first years of the twentieth century was characterized by a significant amount of collaboration, cooperation, and good will, with and from significant parts of the Christian communities of the city.

30 Simon Belkin, Through Narrow Gates: A Review of Jewish Immigration, Colonization and Immigrant Aid Work in Canada (1840-1940) (Montreal: Canadian Jewish Congress/ Jewish Colonization Association, 1966), 38-39, 88.

31 Baron de Hirsch Congregation, 25.

32 Jan Goeb, History of the Jews in the Maritimes, Undated typescript, Jewish Historical Society Fonds, MG 20-Vol. 561-7, Nova Scotia Archives, Halifax, 11.

33 Ira Robinson, A History of Antisemitism in Canada (Waterloo, ON: Wilfrid Laurier University Press, 2015), 54. 


\section{Victorian Reform, Protestant Ethics, and the Society for the Prevention of Cruelty in Halifax}

Noted historian of Nova Scotia and Halifax, Judith Fingard, in writing about the Nova Scotia Society for the Prevention of Cruelty (SPC), observed that "the anti-cruelty movement, of which it was a part, has been virtually ignored by Canadian historians." ${ }^{34}$ While I cannot remedy the situation and present an exhaustive historical account of the SPC or of the animal welfare movement more broadly, it is important to note the existence of contemporary national and international contexts of debates over animal cruelty and to underline the fact that the Nova Scotia SPC must be understood in terms that place it within the overall social and legal history of animal welfare organizations, as they originated in the United Kingdom, ${ }^{35}$ and grew in Canada, ${ }^{36}$ and the United States. ${ }^{37}$ In the 1913 prosecution of Rabbi Levitt, the broader national and international contexts would come to play significant and under-explored roles.

As with anti-cruelty movements elsewhere, the Nova Scotia SPC (and SPCA as its nomenclature and functions changed) in its foundation and activities at the time of the Levitt case fits into the broader context of Victorian and Edwardian, or in the United States historical taxonomy, Gilded Age, social reform movements. James Turner demonstrates how the emergence of the SPCA in England ran in parallel with a period of fervent evangelical agitation. ${ }^{38}$ Janet Davis traces the intellectual and theological origins of concern over animal welfare to periods of increased religiosity during the Second Great Awakening in the United States and the continuing influence of a particular Protestant ideology.

... this era of evangelical revivalism and social reform was essential to the birth of an organized animal welfare movement after the Civil War. The Second Great Awakening put a native-born Protestant stamp on

34 Judith Fingard, The Dark Side of Life in Victorian Halifax (Porters Lake, NS: Pottersfield Press, 1989), 171.

35 Antony Brown, Who Cares for Animals? 150 Years of the RSPCA (London: Heinemann, 1974).

36 Beatrice Johnston, For Those Who Cannot Speak: A History of the Canadian Society for the Prevention of Cruelty to Animals, 1869-1969 (Chomedy, PQ: Dev-Sco, 1970); The Canadian Society for the Prevention of Cruelty to Animals (Montreal: CSPCA, 1886).

37 Diane L. Beers, For the Prevention of Cruelty: The History and Legacy of Animal Rights Activism in the United States (Athens: Ohio State University Press/Swallow Press, 2006).

38 James Turner, Reckoning with the Beast: Animals, Pain, and Humanity in the Victorian Mind (Baltimore: Johns Hopkins University Press, 1980), 20-22. 
the universalizing mission of animal kindness. The Awakening stressed the potential for human perfectibility on this earth, rather than passive acceptance of God's will. Religious revivalism highlighted the power of free moral agency to combat social injustice. ${ }^{39}$

Grounded in a deeply and overtly Christian moral vision, these movements sought greater protections and rights for women and children, as well as animals. "They made "cruelty" into a social problem and wedded sentimentalism to liberal rights discourse to expand public responsibility for animals and children." 40

In Halifax and elsewhere, they sought to inculcate a proper moral vision and practice, and to improve general welfare with an emphasis on the links between a proper education and the embodiment of moral values. ${ }^{41}$ Social and fraternal organizations not only forged the basis for a rising middle class identity in Halifax, but concretized denominational solidarity. They later served as the structural bases upon which the purely private associational form took on public functions of welfare and reform, especially in terms of temperance and the social emphasis on the moral educational value of work. ${ }^{42}$ These organizations battled against the worst consequences of moral failure, often infused with issues of alcohol abuse, in their campaigns against rampant criminality and especially prostitution. ${ }^{43}$ They combatted the sources of cruelty and neglect in their struggles for temperance.

In Canada the rapid industrialization and urbanization of the Laurier era created or threw into sharp relief a host of social ills. Red light districts abounded in the towns and cities, alcoholism increased sharply, the exploitation of workers became blatant and the failure of traditional institutions to provide security for the less fortunate was increasingly manifest. Rural residents were alarmed not only by the moral and social problems of the cities and towns but also by the depopulation of their own

39 Janet M. Davis, The Gospel of Kindness: Animal Welfare and the Making of Modern America (Oxford: Oxford University Press, 2016), 27-28.

40 Susan J. Pearson, The Rights of the Defenseless: Protecting Animals and Children in Gilded Age America (Chicago: University of Chicago Press, 2011), 19.

41 Robert Nicholas Bérard, "Moral Education in Nova Scotia," Acadiensis 14, no. 1 (1984).

42 David A. Sutherland, "Voluntary Societies and the Process of Middle-class Formation in Early Victorian Nova Scotia," Journal of the Canadian Historical Association 5, no. 1 (1994).

43 Fingard, The Dark Side of Life in Victorian Halifax. 
communities. Nova Scotians, who were noted for their strong church allegiance, tended to look to the clergy for leadership in solving their problems. The latter proposed as a general solution implementation of the social gospel - a fundamental reform of society on the basis of Christian principles. $^{44}$

The industrialization and commercial growth in Canada that had presented immigrant Jews with opportunities to establish and to build a community in Halifax had created a city of conflict, criminality, and social ills. It is hardly surprising, given the history and sociology of Nova Scotia as fundamentally Christian, divided between Protestant denominations and the Roman Catholic Church, that the social reform movements would not only be influenced by religious tenets, but that the institutional structures put into place would reflect the faith-based distinctions abroad more generally in the city. ${ }^{45}$ Given the significant presence of African Canadians in Halifax since the days of the United Empire Loyalists, a distinct set of racially segregationist structures and norms also operated in the city and its social welfare apparatus.

Renée Lafferty emphasizes the core values of denominational divisions in the ideology and culture, as well as the organizing principles at work in child welfare. "Denominational partitions dismissed by some as unnecessary (or even damaging) were considered by others to be vital to ensuring a child's future-this future being thoroughly entwined with the specific culture into which the child was born." 46 Social welfare in Halifax from Victorian times onwards was infused with Christian values and embedded in denominational structures. Significantly, Judith Fingard described the anti-cruelty movement in Halifax, embodied in the SPC, as at one and the same time the "most active interventionist society in late nineteenth-century Halifax" and as "more secular in its orientation than other voluntary organizations." 47

44 E.R. Forbes, "Prohibition and the Social Gospel in Nova Scotia," Acadiensis 1, no.1 (1971): 14.

45 David A. Sutherland, "Race Relations in Halifax, Nova Scotia, During the Mid-Victorian Quest for Reform," Journal of the Canadian Historical Association 7, no. 1 (1996); Judith Fingard, "Race and Respectability in Victorian Halifax," Journal of Imperial and Commonwealth History 20, no. 2 (1992).

46 The Guardianship of Best Interests: Institutional Care for the Children of the Poor in Halifax, 1850-1960 (Montreal: McGill-Queen’s University Press, 2013), 21.

47 The Dark Side of Life in Victorian Halifax, 171; "The Prevention of Cruelty, Marriage Breakdown and the Rights of Wives in Nova Scotia, 1880-1900," Acadiensis 22, no. 2 (1993). In 1880, the Nova Scotia legislature changed the law to extend the powers of the SPCA especially in child protective matters in An Act to amend the Act to incorporate the 
The first national anti-animal cruelty provisions in Canada were enacted in $1869 .{ }^{48}$ In the same year, the Canadian Society for the Prevention of Cruelty to Animals was incorporated in Quebec. ${ }^{49}$ Among the founders and early leaders of the Society in Montreal were the Joseph brothers, Jacob Henry and Jesse. Members of an established Quebec Jewish family, they were prominent businessmen, who took active roles in various commercial enterprises, and in public service and charity work. Jacob was identified with the Montreal General Hospital and Jesse was for many years a prominent and active member of Shearith Israel, the Spanish and Portuguese synagogue, the oldest in Canada. ${ }^{50}$ Joining the Josephs among the earliest public supporters of the Society and its work for animal welfare was the Rev. Meldola de Sola. ${ }^{51}$ Meldola de Sola was the son of the Rev. Dr. Abraham de Sola, longtime rabbi of the Spanish and Portuguese Synagogue. Meldola succeeded his father in 1882 and became the first Canadian-born rabbi to serve a congregation in that country. ${ }^{52}$ At a time when many Protestant ministers failed to offer their public backing for the Society, de Sola was one of the few religious leaders in Montreal to deliver a sermon on kindness to animals as a core ethical value and was staunch in his support of the Society and its goals. ${ }^{53}$ In its early days in Montreal, the Society's leadership featured some of the most prominent and influential members of the city's Jewish community. In its beginnings, it did not proclaim the overtly Christian evangelical ideology of the English, or other Canadian Societies, but instead it was more broadly humanist in its orientation, although from its foundation it was dominated by the English-speaking Protestant social and commercial elite of the city.

In Nova Scotia, the SPCA was incorporated eight years later in 1877. The SPCA itself makes much of the history of Nova Scotia as a groundbreaking jurisdiction in the field of the punishment of animal cruelty, but a more

Nova Scotia Society for the Prevention of Cruelty to Animals, 43 Vict. c. 68 and in 1909 the broader remit of the SPCA was recognized as it was renamed in section 1, "The Nova Scotia Society for the Prevention of Cruelty," An Act to amend chapter 86 of the Acts of 1877, entitled "An Act to incorporate the Nova Society for the Prevention of Cruelty to Animals," 9 Edw. VII, c. 165.

48 An Act Respecting Cruelty to Animals, SC 1869, c. 27; 32-33 Vict., c. 27.

49 Johnston, For Those Who Cannot Speak.

50 Arthur Daniel Hart, ed., "Jacob Henry Joseph," in The Jew in Canada (Toronto: Jewish Publications, 1926), 330; “Jesse Joseph,” ibid., 331.

51 Johnston, For Those Who Cannot Speak, 8.

52 Hart, The Jew in Canada, 87.

53 Johnston, For Those Who Cannot Speak, 8. 
careful examination of the record puts a somewhat different spin on matters. The modern day claim by the SPCA is that "the Acts of Nova Scotia made provisions for public whipping to be the punishment for persons convicted of cruelty to animals." 54

The assertion becomes less significant when the legislative context and the 1824 statute lauded by the Society itself are examined more carefully. The 1824 statute, An Act to punish Persons guilty of maliciously killing or maiming Cattle, ${ }^{55}$ replaced the similarly titled Act to prevent the malicious killing or maiming of cattle, from $1768 .{ }^{56}$ A plain reading of the laws indicates that the provisions are, unsurprisingly given the historical and legal contexts in which they were passed, not aimed at animal welfare per se, or at the prevention of cruelty as a moral imperative. The statutes granted relief "by action of trespass or upon the case" to the animal's owner. The 1768 law gave the owner the right to recover treble damages against anyone who "maliciously, unlawfully and willingly" killed or maimed an animal not belonging to him. The 1824 law, that introduced the penalty of whipping, repeated these provisions of the earlier Act, including the use of the "maliciously, unlawfully and willingly," but not "cruelly." The penalty of whipping was an alternative to the usual punishment of imprisonment and was solely within the discretion of the Court. ${ }^{57}$ Imprisonment or whipping was not permitted if the owner had proceeded by way of damages, and conversely, the infliction of the punishment barred any subsequent action for monetary recompense.

Whipping was not, as the SPCA narrative would have it, the punishment for cruelty to animals. It was a punishment available in some cases, largely as a discretionary alternative. The action that gave rise to the punishment was not characterized as "cruelty" but required malice and unlawfulness. The Nova Scotia statutes were little more than treble damages provisions within the normal field of tort law relating to trespass to chattels and similar and related general actions in civil liability. The actions targeted by the legislation were those of the legal stranger, a third party who "maliciously" interfered with the property rights of "the party aggrieved." There is no mention of cruelty because cruelty was completely irrelevant to the legal issues of title to the animal. Killing, maiming, wounding, or otherwise hurting an animal could be

54 "History of the Nova Scotia SPCA," http;//spcans.ca/old_joomla_site/about-us/history. html.

55 Nova Scotia Statutes at Large, 4 \& 5 Geo. IV, c. IV.

56 Nova Scotia Statutes at large, 8 Geo. III.

57 Nova Scotia Statutes at Large, 4 \& 5 Geo. IV, c. IV, II. 
done, especially in so far as killing was concerned, in a humane way, but would still constitute an unlawful interference with the rights of the owner of the animal. An owner of the animal could, within this statute, kill, maim, wound, or hurt his own animal with impunity. As Lesli Bisgould points out, this idea of the animal as chattel has not only informed much of the legal debate over cruelty legislation, but it is clearly one that is situated at an entirely different normative level than a focus on the suffering of the animal as the core harm to be dealt with in a legal framework. 58

Notwithstanding this attempt to rewrite the legal history of its own actions and the basis of the prevention of cruelty to animals in Nova Scotia law, the SPCA was among the first organizations of its type in Canada and one of the most active anti-cruelty groups in the country. The SPCA was incorporated by provincial statute in 1877 and the prevention of cruelty to animals and the "conviction of persons offending against the same" were its key organizational objectives. ${ }^{59}$ From its origins, the SPCA was permitted to call upon the police to assist in its tasks and to have special officers appointed as agents of the Society to engage in enforcement actions. ${ }^{60}$ One of the most intriguing aspects of the Halifax shechita case can be found in this official legislative and bureaucratic melding of private and public functions that characterizes the existence of the SPCA. An incorporated body is invested with the protection of a legislatively identified public good, preventing animal cruelty. ${ }^{61}$

This change in the nature of the legislation from the early statutes in Nova Scotia is at the heart of debates over the criminalization of the Jewish mode of slaughter and those instances of prosecutions examined here. Anti-cruelty legislation identifies the protection of animals, and ensures their humane treatment, because these values are incorporated into legislation as public goods, as matters of general interest and value in which the state justifiably interferes. In addition to the rhetorical and juridical transformation of animal cruelty into an issue of public morality, for the SPCA in Nova Scotia and its counterparts elsewhere, "as private organizations delegated police powers, they

58 Animals and the Law (Toronto: Irwin Law, 2011), 34 et seq.; Joyce Tischler, The History of Animal Law, Part I (1972-1987), 1 Stanford Journal of Animal Law and Policy 1 (2008).

59 An Act to incorporate, "The Nova Scotia Society for the Prevention of Cruelty to Animals," Statutes of Nova Scotia, 40 Vict., c. 86, § 4.

60 Ibid., and An Act to amend the Act to incorporate the Nova Scotia Society for the Prevention of Cruelty to Animals, Statutes of Nova Scotia, 43 Vict., c. 68 (1880).

61 Angus Nurse, Beyond the Property Debate: Animal Welfare as a Public Good, 19 Contemporary Justice Review 174 (2016). 
extended the arms of government because they helped create and enforce new laws." 62 When a public norm is protected by such legislative intervention, a public agency, police or a government department, are tasked with ensuring the enforcement of the law through preventing offending behavior, and if that fails, with ensuring the pursuit of offenders through the courts. In animal cruelty cases, however, the Nova Scotia legislature, like that in many other jurisdictions, delegated the prevention, enforcement, and prosecution powers to a private body, the SPCA. That private body had, and still has, the power to investigate, to seize property, to charge, and to bring cases before the courts. In other words, they are the animal police, and can and do invoke the authority and powers of the courts, the institutions of the public enforcement of laws, as a private body enforcing public morals. ${ }^{63}$

In this sense, the 1913 summons of the shochet was a strong embodiment of the move away from social welfare and rehabilitation organizations and programs, towards a greater institutional emphasis on the policing of the types of anti-social behavior that had been targeted by fraternal and other bodies in the pre-World War I era. Social welfare intervention and rehabilitation were soon replaced by an emphasis on law and order. ${ }^{64}$ The structures of law and order in Halifax, from the police to the courts, continued to embody many of the class and denominational characteristics of earlier reform movements. ${ }^{65}$ The SPCA was no exception.

In cases like the Halifax prosecution, the SPC (re-named following its increased jurisdiction in child welfare) acted as investigator and prosecutor, combining the functions of police and attorney general, always in the name of the public, legislatively enshrined value of preventing cruelty to animals. The SPC was a single-issue body. It is focused on the prevention of cruelty. That was its private, corporate raison d'être and its public mandate. Unlike politicians or other public officials, it took, in a manner completely consistent with its public / private functions, a view of the public good and normative values that was singular in its focus. Animal welfare and the prevention of

62 Pearson, The Rights of the Defenseless, 19.

63 Jerry L. Anderson, The Origins and Efficacy of Private Enforcement of Animal Cruelty Law in Britain, 17 Drake Journal of Agricultural Law 263 (2012); Gordon Hughes and Claire Lawson, RSPCA and the criminology of social control, 55 Crime, Law and Social Change 375 (2011).

64 Michael Boudreau, City of Order: Crime and Society in Halifax, 1918-35 (Vancouver: University of British Columbia Press, 2012).

65 Greg Marquis, “The History of Policing in the Maritime Provinces," Urban History Review 19, no. 2 (1990). 
xxiv | Introduction: Jews, Shechita, and the Law

cruelty, these were the aims of the investigative, charging, and prosecutorial functions of the SPC. Other public values, unless they formed part of a broader legislative scheme on the protection of animals, could not and would not enter into the SPC's calculations, or act as determining factors in its decisions to prosecute acts of cruelty. The ideas of religious freedom, of core communal self-identity among Halifax Jews, of commandments from God to kill animals in a particular fashion, none of these could or did form the frame of reference for the SPC, whose sole aim was the prevention of cruelty to animals, women, and children, God's helpless creatures. A state prosecutor might well have considered the public interest more broadly to take into account possibly competing normative concerns, and have engaged in a specific and calculated balancing assessment of animal welfare on the one hand, and religious freedom on the other, in deciding whether to prosecute Rabbi Levitt for the practice of shechita. An organization such as the SPC, acting under its legislative mandate and in accordance with its own internal normative frame focused solely on the fundamental imperative of protecting animals, could not imagine in 1913 that any competing values might be at play. The case presented a chance to prosecute an obvious instance of inflicting needless suffering on an animal. The SPC wished to use the prosecution of the shochet to begin a campaign of education about, and pursuit of, slaughtering practices throughout the province that did not use stunning before killing. ${ }^{66}$

66 “A Campaign Against Butchers," Halifax Herald, April 28, 1913. 